\title{
The Image of Civilian Heroes in Chinese Films and TV Series
}

\author{
Juxiang Wen \\ College English Teaching Department \\ Zaozhuang University \\ Zaozhuang, China
}

\begin{abstract}
Theme expression and character modeling play a vital role in films and TV series. The civilian heroes in Chinese films and TV series show some typical characteristics, such as strong awareness of their country and nation, being from different fields, their brave spirit and bumpy life, the grassrooted characteristic and individualization. The reasons for the image of civilian heroes are also interpreted from three aspects: the historical background, culture influence and the call of civilian heroes in new era.
\end{abstract}

Keywords-civilian heroes; Chinese films and TV series; awareness of one's country and nation; grass-rooted characteristic

\section{INTRODUCTION}

In Chinese history, heroes are a permanent topic and they play a vital part in films, TV series and other kinds of art. Nowadays, more and more civilian heroes appear on the screen. [1]They left an unforgettable impression on the audience. They play an important role in the progress and development of modern society in China. Therefore, we need to pay enough attention to the characters of $t$ heroes, especially the civilian heroes in the films and TV series.

\section{THE CHARACTERISTICS AND CONNOTATION OF CIVILIAN HEROES IN CHINESE FILMS AND TV SERIES}

\section{A. Awareness of Civilian Heroes' Country and Nation}

In history and revolutionary films and TV series, it's easy for us to found that the heroes are usually related to their nation, country and the war and risk their lives. Collectivistic heroism is the apparent and important trait of Chinese heroes. The benefits of their group, country and nation are always put on the first place and always prior to personal interest. The civilian heroes in China are also stick to the principle. There is full of heroism in the noble belief, spirit and value. [2]

For example, Zhu Kaishan in the TV series Brave Journey to Northeast China, and Chen Shouting in the TV series Big Dyehouse are the civilian heroes in modern art works. They have different identities and personalities. However, they have a mutual spiritual characteristic they will rush toward the difficulty and risk their lives for their country's hope and interest. In the cartoon film Mr.
Black: Green Star (2010), all the civilian hero' behaviors (Mr. Black) represent the law enforcement unit of the forest police, and protect the interests of the forest residents without hesitation. There are always a large number of white cat police officers to work with Mr. Black whenever he makes efforts to arrest the criminals. When one female fan, a sheep shyly ask Mr. Black for his telephone number, he answered " 110 " which is full of collectivism.

\section{B. Civilian Heroes from Different Fields}

One old Chinese saying said: "Every profession produces its own leading authority. And every trade has its master." Civilian heroes in Chinese films and TV series are come from different fields.

There are many civilian heroes from films about real-life stories, such as Xu Zhenguo in Jin Pai Gong Ren, Alim in I'm Alim, and so on. Xu Zhenguo, who broke the world record two times, grows to a gold worker with forte skills from an ordinary worker who even didn't finish his junior high school. Xu Zhenguo, an ordinary worker did extraordinary things and made remarkable achievements in his position and his spirit is encouraging people moving forward. [3]Alim is a Uygur guy from Xin Jiang and sells barbecued lamb kebabs in Guizhou. [4]He tries his best to create an Alim education fund organization to help those students from poor family.

There many TV series about civilian heroes in history stories, such as The Merchants of Qing Dynasty (Wang Chaozong). [5]Wang Chaozong has been always encouraging other merchants to put the national interests in the first place. He is competent and wise. He always ignores his personal gains and losses and solves the problems from the situation as a whole though he is an ordinary person.

Shun Liu in TV series My Brother is Named Shun Liu, $\mathrm{Ga} \mathrm{Zi}$ in the film Zhang $\mathrm{Ga}$ the Soldier Boy, Xu Sanduo in Soldier Sortie and Pan Dongzi in the film Bright Red Star are also civilian heroes in military films and TV series. Although Zhang Ga and Pan Dongzi are little boys at the beginning, they gradually grow into brave and smart young heroes with a strong will.

There are still many civilian heroes in crime films and TV series, such as Xue Bing called "crazy dog" policeman in Resolute Control, the female police Chief Ren Changxia in 
TV series Ren Changxia, Li Xidong in Gong'an Juzhang. On one hand, these heroes all have a strong will and persistence. On the other hand they are experiencing the sufferings and hardships like other ordinary people.

\section{Brave Spirit and Bumpy Life of Civilian Heroes}

Because of the characteristics of strong collective Chinese heroism, heroes think that it's worthwhile and necessary to sacrifice individual interests for public benefits. Therefore, Chinese heroes often show their brave, dauntless sacrifice spirit and their life is usually full of hardships. Many films and TV series take the main character's sufferings, sacrifice or death as the final sublimation, such as My Brother is Named Shunliu, Crouching Tiger, Hidden Dragon and so on. This tragic tendency reinforces their heroic image to a large degree.

Let's take the film Zhang Ga the Soldier Boy for example. Zhang $\mathrm{Ga}$, the brave little hero, is full of confidence and strong belief of winning the war. Zhang Ga loved his grandma, the only family member because grandma care about him. At the beginning of the story, although his grandma tried her best to protect Chinese Eighth Route Army, his life was full of happiness. One day, his grandma was killed by the enemy, and the happy family was completely destroyed. However, Zhang Ga, a lovely, brave and strong boy is fearless in front of the enemy, and shows the invincible spirit. At the beginning, Shunliu was a little educated farmer. He gradually grows into a true soldier, who is extremely brave and abide by the rules. When his sister was raped and his sister-in-law was killed by enemy, he was determined to revenge for them. However, the enemy surrendered at that time, Kuomintang troops accepted the surrender of Japanese emperor. According to Armistice Agreement, Shunliu couldn't shoot the surrendered enemy. Shunliu shot all the Japanese flags, all the military flags and Shiyuan's cremation urn. At last, Shunliu killed himself by detonating grenades.

\section{The Grass-rooted Characteristic and Individualization of Civilian Heroes}

Nowadays, the civilian heroes in Chinese films and TV series are not like the national heroes in the history ones. The national heroes like Liu Hong in the film Railway Guerilla, Jiang Jie in TV series Red Crag, are usually perfect figures without any shortcomings. [6]We can easily find out the prevailing characteristics of them. They usually have a strong will, cool mind, good-looking appearance, perfect personality, extraordinary ability and so on. They are not only willing to risk their lives to rescue the people in trouble but also show all the virtues of loyalty, filialness, benevolence, righteousness, courtesy and faith. They are so perfect that people tend to feel strange and far away from the real life. However, civilian heroes these days are often grassrooted and individualized. These civilian heroes show their different aspects and the complexity like in the real life. For example, Ge Erdan in the military TV series A Unque Militiman keeps his civilian figure from the beginning to the end. On one hand, Ge Erdan didn't become the general or leaders in the end. The highest title of him was a small team leader of the trainband in the Ta Wan village. On the other hand, he even didn't take any part in the combat. The most glorious thing he did throughout the TV series was to coordinate with Eighth Route Army to fight against Japanese army. Although his social status was relatively low and he didn't make any feat, his civilian identity effectively closes the distance between the hero and the audiences.

\section{THE REASONS FOR THE IMAGE OF CIVILIAN HEROES}

Why does the image of civilian heroes in Chinese films and TV series present the above characteristics? Civilian heroes, as the result of historical background and culture influence in a particular period are a concept full of culture connotations. This paper discusses the reasons from the following aspects.

\section{A. The Historical Background}

In the few past decades, our heroes have changed from the perfect figure to civilian heroes. These hero figures are carrying a profound and complex task of cultural expression, and kinds of social ideals. As is known to all, the United States, as a big country of immigrants, it doesn't have profound cultural and historical origins like the four ancient civilization countries. When the first Puritans came to the New World, they showed unusual courage, perseverance and adventurous spirit. These may be the earliest historical origins of heroism. [7]

Although The United States is also a country including many races and nations with different cultures and customs, she did not experience long-time integration with each other. Therefore, they maintain the cultural differences of their ancestors, which are the core spirit of the individualism in the United States. Meanwhile, the short history makes them form a spirit of self-confidence, innovation, enterprising and self-seeking, which lay the foundation of individual heroism and provide the fertile soil for its development. Individual heroism is increasingly becoming the core values and cultural beliefs of Americans these days. On the contrary, China is a country with the ancient civilization of more than five thousand years. Chinese people know that today's happy life is fought for by the unity, sacrifice and unremitting selfimprovement. Gu Yanwu, the famous thinker and historian in the Qing Dynasty said "Every citizen should take the responsibility for the fate of their country". Fan Zhongyan, the famous writer in the Song Dynasty, said "One should be the first to worry for the future of his country and the last to enjoy universal happiness". There are also the sayings like "It's better to die than to live when life is a disgrace". Therefore, the Chinese heroes are usually brave to take the responsibility and have a broad mind. They face death calmly with no regrets, sacrifice for others and ask for nothing in return. Civilian heroes are no exception. They are also the collective heroes.

\section{B. Culture Influences}

Chinese people, deeply influenced by the Confucian culture, think that heaven, earth and human beings are a harmonious unity. The thought emphasizes that the existence 
of the individual is integrated into the society. Collectivism is deeply rooted in Chinese traditional culture, and it is the essence of Oriental culture. The world view, collective interests higher than people's individual benefits in Chinese traditional culture, has been fully expressed and displayed in the screen. Therefore, the heroes are willing to abandon any personal benefits and sacrifice their own happiness for their national interests.

Chinese heroes are greatly influenced by Chinese chivalry spirits such as having a strong sense of justice and ready to help the weak, being indifferent to fame and fortune, being grateful, stressing on righteousness and despising personal benefits. Chinese chivalry is deeply respected and beloved by people in China. That's why Chinese heroes are usually perfect. At the same time, most Chinese heroes are suffering the great mercy, which is usually doomed to the tragic tendency of Chinese heroes. That's not in America. Although American culture is a typical hybrid culture because of the diversity of American society, it's mainly influenced by the Christianity-centered European culture. Its essence spirits are democracy, freedom and independence. As the declaration of independence proclaimed, "all human beings are created equally, and the Creator gives them certain non-transferable rights, including the right of life, liberty, and the pursuit of liberty." Individualism is deeply rooted in the traditional western culture. Therefore, western heroes are usually free from worldly bondage to take actions.

\section{The Call of Civilian Heroes in New Era}

The strength of literary works has never been measured by the size of the main events and the level of the characters. A drop of water can reflect the sunlight, so the creators need to focus on the works which reflects the grand theme through small incidents. Ordinary people working in various positions need to pay attention to. The characteristic of civilian heroes' identity makes the audiences be closely related to the characters and easy to accept them. The identity of civilian heroes is in conformity with that of the public. Information communication is a two-way social interaction behavior. People always consider the relationship between information and themselves before they decide to accept it.

The successful deeds of the civilian heroes are closely related to the ordinary people, while success of the traditional heroes needs to be looked up to and can never be followed or achieved by ordinary people. The advantages of TV media not only lie in the breadth of the communication, but also have great model effect on the behavior of the audience. The success of civilian heroes appears among the ordinary people, and the things they did are closely related to ordinary people in daily life and can easily be replicated. Therefore, it can guide the public's concrete behavior and is a good example for the public to learn from. Fried Bread Stick Brother, Egg Brother and so on are no longer exclusive to the individuals but become the representation of conscience and integrity. The honest and trustworthy civilian heroes will appear everywhere. Fried Bread Stick Brother, Liu Hong'an, like other thousands of college graduates, set up his own business after changing a few jobs, and never touched the bottom line of moral standard. The traffic police officer, Meng Kunyu commits his youth and passions to his position. These civilian heroes are living around us and easily arouse people's affection.

\section{CONCLUSION}

In 21 th century, peace and development are the two main themes of the world. We don't need the mythical heroes like Prometheus to rescue the world. The perfect traditional heroes are too far away from people's daily life. That not means we don't need heroes today. However, we are more longing for the emergence of heroes than ever before and calling for the heroes. They are the civilian heroes who are the new era calling for, creating social harmony, or struggling to fulfill their "Chinese dreams". They are not the elite but they make remarkable and extraordinary achievement in their ordinary positions, and their spirits shines splendidly in the world.

\section{REFERENCES}

[1] Zhang Tiehu, "The interpretation of civilian heroes' image in Hollywood movies," Movie Literature, 2017(7), pp.63-65.

[2] Hao Jian, "A study on cultural identity of the superhero movies -Taking Superman, Batman, and Spiderman as the examples," Movie Review2016(18),pp.86-88.

[3] Li Bo, "Encourage the public by the civilian heroes'deeds," China Art, 2018.2.9.

[4] Zhao Zheng, "A panoramic view of I'm Alim - A capitalized civilian hero in the context of the times," Contemporary Cinema 2014(8), pp.124-126.

[5] Zhou Anhua, "Gorgeous music of civilian heroes played in the big era -- Comments on the TV series The Merchants of Qing Dynasty," China Television, 2015(3), pp.50-52.

[6] Qiu Fei, "the formation and influence of civilian heroes -taking the TV series Don't Let Me See as an example, "Contemporary TV,2015(12), pp.22-23.

[7] Peng Chunju, "Forrest Gump: the image of the civilian heroes and its Postmodern presentation", Movie Literature,2014(16), pp.124-125. 